\title{
Assessing high performance: A South African case study
}

\begin{tabular}{|c|c|}
\hline $\begin{array}{l}\text { Authors: } \\
\text { Christiaan Ha } \\
\text { André de Wa } \\
\text { Phillip Parson }\end{array}$ & stingh $^{3}$ \\
\hline Affiliations: & \\
\hline${ }^{1}$ Business Sch & ool, Nelson \\
\hline $\begin{array}{l}\text { Mandela Met } \\
\text { University, So }\end{array}$ & $\begin{array}{l}\text { ropolitan } \\
\text { uth Africa }\end{array}$ \\
\hline $\begin{array}{l}{ }^{2} \mathrm{HPO} \text { Center, } \\
\text { the Netherlar }\end{array}$ & $\begin{array}{l}\text { Hilversum, } \\
\text { ds }\end{array}$ \\
\hline $\begin{array}{l}{ }^{3} \text { Department } \\
\text { Cape Peninsu } \\
\text { Technology, S }\end{array}$ & $\begin{array}{l}\text { of Education, } \\
\text { la University of } \\
\text { outh Africa }\end{array}$ \\
\hline $\begin{array}{l}\text { Correspondin } \\
\text { André de Wa } \\
\text { andredewal }\end{array}$ & $\begin{array}{l}\text { g author: } \\
\text { @planet.nl }\end{array}$ \\
\hline $\begin{array}{l}\text { Dates: } \\
\text { Received: } 30 \\
\text { Accepted: } 09 \\
\text { Published: } 21\end{array}$ & $\begin{array}{l}\text { Sept. } 2016 \\
\text { Aug. } 2017 \\
\text { June } 2018\end{array}$ \\
\hline $\begin{array}{l}\text { How to cite } \\
\text { Hattingh, C., } \\
\text { Parsons, P., } 2 \\
\text { high perform } \\
\text { African case s } \\
\text { African Journ } \\
\text { Management } \\
\text { https://doi.or } \\
\text { sajbm.v49i1.3 }\end{array}$ & $\begin{array}{l}\text { is article: } \\
\text { e Waal, A. \& } \\
18 \text {, 'Assessing } \\
\text { ance: A South } \\
\text { tudy', South } \\
\text { ll of Business } \\
\text { 49(1), a3. } \\
\text { g/10.4102/ }\end{array}$ \\
\hline $\begin{array}{l}\text { Copyright: } \\
\text { @ 2018. The } \\
\text { Licensee: AOS } \\
\text { is licensed un } \\
\text { Creative Com } \\
\text { Attribution Li }\end{array}$ & $\begin{array}{l}\text { Authors. } \\
\text { IS. This work } \\
\text { der the } \\
\text { mons } \\
\text { ense. }\end{array}$ \\
\hline Read online: & \\
\hline 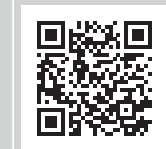 & $\begin{array}{l}\text { Scan this QR } \\
\text { code with your } \\
\text { smart phone or } \\
\text { mobile device } \\
\text { to read online. }\end{array}$ \\
\hline
\end{tabular}

\section{Authors:}

Christiaan Hattingh

ré de Waal $^{2}$

\section{Affiliations:}

${ }^{1}$ Business School, Nelson

Mandela Metropolitan

${ }^{2} \mathrm{HPO}$ Center, Hilversum,

Cape Peninsula University of

Corresponding author:

André de Waal,

Dates:

Accepted: 09 Aug. 2017

Parsons, P., 2018, 'Assessing

high performance: A South

Management 49(1), a3.

https://doi.org/10.4102/

Copyright:

Licensee: AOSIS. This work

is licensed under the

Creative Commons

mobile device
to read online.

\begin{abstract}
The dual challenge of globalisation of competition and global economic slowdown has increasingly forced businesses to do introspection not only in terms of their cost structures, but also in terms of their value proposition in search of sustainable organisational success. Given the limited influence that organisations, in general, have over their external environments, organisations have become more focussed on identifying internal constraints that inhibit rapid responses to market challenges and opportunities, and on identifying the interventions that are most critical to address these issues. This study focussed on the organisational characteristics that drive high performance, derived from De Waal's high-performance organisation (HPO) framework, and proposed interventions to enhance the development of a high performance culture within the case company. Employing a self-administered questionnaire, it was possible to determine the performance of the case company across a range of five critical dimensions for high performance. A detailed analysis of each of the 35 questions provided an in-depth picture of the organisation's strong and weak points and, from this analysis, specific actions to address the areas of weakness were identified. The study confirmed the robustness of the HPO framework employed as well as demonstrating its usefulness to management in terms of a detailed analysis of where the organisation was positioned in terms of the various high performance factors that are linked to organisational success.
\end{abstract}

\section{Introduction}

During the last three decades a fundamental shift has taken place in the global economy, specifically in the period since the 2008 financial and economic crises. As a result of, amongst others, advancing technology making increased globalisation possible, national economies no longer are self-contained entities (Hill 2011). The effect of globalisation has further manifested itself in the global economic slowdown since 2008 when spending became severely constrained and consumers became even more discerning in their value considerations (Gokay 2009). The dual challenge of globalisation of competition and global economic slowdown forced organisations to introspect not only on their cost structures, but also on their value propositions in light of decreasing margins and profits (Viljoen 2016).

One of the industries that was hit particularly hard during the recession was the private security industry in South Africa. Because the police force, in the 1970s, was becoming more focussed on addressing political threats and engaging in addressing political unrest, the government encouraged the private security industry to fill the gap created in traditional police duties (Bodnar 2012). After apartheid ended, the private security industry kept growing because of several trends: rising crime rates, growing unemployment, growing substance abuse amongst the youth, and the absence of a long-term goal to improve policing, law enforcement and prosecution in South Africa (Bodnar 2012). Because of the initial low levels of regulation within the private security industry and the limited business management experience of many of the new entrant companies, the industry underwent a period of rationalisation where many start-ups were absorbed by larger, established corporations. Several large national security companies soon resulted in an industry with a revenue of more than R30 billion and employing more security officers than all police forces in the country combined (Bodnar 2012).

As was the case for most businesses in the period during the 2008 crisis, many private security companies saw a flattening out of growth and profit. This was caused mainly by increased regulation from the local banking industry which created constrained spending, and by new US financial regulatory compliance amendments which introduced an onerous transacting environment for international operators (Bodnar 2012). At the same time, several new smaller niche players entered the market, offering quicker decision-making and a better response to 
market needs coupled with greater price flexibility. This created a 'perfect storm' for the bigger companies in the industry, as the market decreased on one side and affordability came under pressure on the other side, while shareholder expectations kept pressure on cash generation. Many companies reacted by trying to extract more revenue from fewer customers and getting more effort from less employees. However, this strategy proved not to be sustainable, and several companies looked at other methods to establish a more sustainable way forward.

One such method is the application of the highperformance organisation (HPO) methodology that aims at transforming average companies into high-performing ones. In the reported study, an HPO method was used to assess the current strengths, weaknesses and performance of an established South African private security firm. The study aims to answer the following research question: What are the shortcomings in pursuit of high performance that a security service provider in South Africa currently exhibits, and how can these internal constraints be alleviated in pursuit of competitive advantage?

\section{High-performance organisation research in South Africa}

There are a number of examples of high performance research, specific in South African companies. Khoza and Adam (2005) described the experience of Eskom, a South African state utility that developed into one of the most efficient and globally competitive state-owned enterprise. Goldstein and Prichard (2009) discussed the development of South African multinationals, and specifically looked at investment issues and the sustainability of competitive advantage that these multinationals had. Hough et al. (2011) described the turnaround of Nedbank from being one of the worst-performing to becoming one of the best-performing South African banks.

In exploring the factors that led to excellence, Abor (2007) looked at the effect of debt policy on the financial performance of small and medium-sized enterprises (SMEs) in Ghana and South Africa, and found that the capital structure of these firms, especially long-term and total debt ratios, negatively affected the performance of SMEs. Bowen et al. (2010) investigated the nature and extent of value management (VM) practices by professional quantity surveyors in South Africa and found that they predominantly looked at VM as a cost-reduction tool; thus missing a chance to provide clients with services that meet global best practice standards. Mayer and Louw (2011) indicated that cross-cultural conflict, identity and value issues among managers in the South African automotive industry prevent them from achieving high performance. In the same vein, Nienaber (2007) noted that South Africa faces unique competitive challenges that fall squarely within the realm of management to address, but unfortunately there are not enough competent senior managers in the country to achieve this. Researchers like McFarlin, Coster and Mogale-Pretorius (1999), Denton and Vloeberghs (2003), Luthans, Van Wyk and Walumbwa (2004) and Mahajan (2009) also discussed the importance of the further development of the quality of South African managers for the success of South African companies. The same is true for South African employees as Slabbert and Ukpere (2011) concluded in their comparison of the work ethic amongst South African and Chinese workers: There was substantive 'negativity' in the work ethic of the South African labour force, possibly in relation to historical and cultural factors, causing low national productivity. In the same area, McCourt (2006) looked at the way government in South Africa should be managing its public employees in order to increase successful implementation of governmental strategies; thus increasing national development. Oyewobi, Windapo and Cattell (2013) examined the relationship between the extent of business diversification and the performance of construction firms in South Africa, and found no statistically significant differences in the performance of diversified and undiversified firms. Comins and Kraemer-Mbula (2016) described the role innovation hubs played in developing not only South African companies organisationally, but also South African industries economically. One study was performed in South African's security industry. Kokt (2003) looked at diversity issues caused by different cultural backgrounds that do not easily mix and their effects on the performance of work teams in a security company. She found that, instead of cultural differences, the quality of the team leader prevailed in deciding the performance of the team.

In light of the size and importance of the South African business community, it is therefore surprising that no holistic framework for analysing and improving South African organisations to the level of high performance has emerged in the literature. A way forward might therefore be to use a framework that has not been developed specifically for South Africa and to validate it for this country. Such a framework is offered by De Waal (2012), who introduced an $\mathrm{HPO}$ framework consisting of five factors and 35 underlying characteristics which was developed based on data collected worldwide - both in developed and developing countries, including South Africa. In addition, De Waal's HPO framework, has already been employed at a South African company. The question of whether De Waal's HPO framework can be applied to South African organisations is important, as the country continues to rank low internationally in terms of competitiveness (Strauss \& du Toit 2010) and industries - private- and state-owned - are still poorly managed (Sharma 2012). Thus, management of South African organisations urgently need to find a framework that can help them in their quest for high performance, so they can apply its principles with insight (Nienaber 2007). This will not only help them improve the performance of their companies, but also help increase the competitiveness of South Africa as a whole (Nienaber 2007). 


\section{The high-performance organisation framework}

The HPO framework was developed from a descriptive literature review (Phase 1) and an empirical study in the form of a worldwide questionnaire (Phase 2) (De Waal 2010 [2006]; 2012). The first phase of the research consisted of collecting studies on high performance and excellence that were to be included in the empirical stage. Criteria for inclusion were based on whether the study (1) was aimed specifically at identifying HPO factors or best practices; (2) consisted either of a survey with a sufficiently large number of respondents that the results could be deemed (fairly) representative, or of in-depth case studies of several companies where the results were at least valid for more than one organisation; (3) employed triangulation by using more than one research method; and (4) included written documentation containing an account and justification of the research method, research approach and selection of the research population, a well-described analysis, and retraceable results and conclusions that allowed the quality of the research method to be assessed. The literature search yielded 290 studies that satisfied all or some of these four criteria. HPO characteristics were then identified and entered into a matrix. After that, the 'weighted importance', that is, the number of times a characteristic occurred in the individual study categories, was calculated for each. Finally, the characteristics with a weighted importance of at least $6 \%$, a total of 35 , were chosen as the characteristics that potentially make up an HPO.

During Phase 2, the 35 potential HPO characteristics were included in a questionnaire which was administered during lectures and workshops given by the author and his colleagues to managers all over the world. The respondents of the questionnaire were asked to indicate how well their organisation performed on the various HPO characteristics on a scale of 1 (very poor) to 10 (excellent) and also how its organisational results compared with its peer group. Two types of competitive performance were established (Matear, Gray \& Garrett 2004): (1) relative performance (RP) versus competitors: RP $=1-[(\mathrm{RPT}-\mathrm{RPW}) /(\mathrm{RPT})]$, in which $\mathrm{RPT}=$ total number of competitors and $\mathrm{RPW}=$ number of competitors with worse performance; (2) historic performance of the past 5 years (possible answers: 'worse', 'the same' or 'better'). These subjective measures of organisational performance are accepted indicators of real performance (Dawes 1999; Heap \& Bolton 2004; Jing \& Avery 2008). The questionnaire yielded 2015 responses from 1470 organisations. Using a correlation analysis and a factor analysis, 35 characteristics, categorised in five factors, were extracted and identified that had both a significant and strong correlation with organisational performance. The factor scales showed acceptable reliability (Hair et al. 1998) with Cronbach's alpha values close to or above 0.70 . These five factors and their accompanying 35 characteristics (see Appendix 1) show a direct and positive relationship with the competitive performance of the organisation. These are as follows:

- HPO Factor 1: Management quality. HPO managers focus on encouraging belief and trust in each other. They value loyalty and live with integrity. They treat their people with respect and maintain individual relationships with employees. HPO managers are committed and have a strong set of principles and standards. They are supportive and help employees in achieving their results and also hold them accountable for these results. HPO managers act as a role model for the rest of the organisation.

- HPO Factor 2: Openness and action orientation. HPO managers value the opinions of employees and always involve them in important business and organisational processes. Making mistakes and taking risks is something that is always encouraged in an HPO, as this is considered to be an opportunity to learn, develop new ideas and exchange knowledge for improvement.

- HPO Factor 3: Long-term orientation. Long-term commitment is more important than short-term gain for an HPO. Stakeholders of the organisation are benefiting from this long-term orientation and are sure that the organisation is maintaining mutually beneficial longterm relationships with them. HPO managers are committed to the organisation and new positions are filled from within the organisation. An HPO is a secure and safe workplace where people feel free to contribute the best they can.

- HPO Factor 4: Continuous improvement and renewal. An HPO has a unique strategy that makes the organisation stand out in the sector. The organisation is responsive to market developments by continuously innovating its products and services; thus creating new sources of competitive advantage. An HPO makes sure it keeps core competencies inside and outsources non-core competencies.

- HPO Factor 5: Employee quality. HPO employees are flexible and resilient, as they are trained (both formally and on the job) to achieve extraordinary results. As a team they are diverse and therefore complementary, so they can deal with a variety of issues and propose ideas for improvement.

An organisation can evaluate its HPO status by conducting an HPO diagnosis. The HPO diagnosis process starts with an HPO awareness workshop for management and other interested parties. During this workshop, the organisation gets acquainted with the HPO framework, the HPO diagnosis and the possible HPO transformation process. During the actual HPO diagnosis, management and employees fill in the HPO questionnaire, consisting of questions based on the 35 $\mathrm{HPO}$ characteristics. The questionnaire has been validated and the statistics performed on data collected worldwide. Therefore it is important to mention that the main principles of the HPO framework remain unchanged, regardless of the type of company or industry being diagnosed. The individual scores are averaged to provide scores on the HPO factors for the complete organisation. These average scores indicate 
which HPO factors and characteristics the company needs to improve in order to become an HPO. It should be noted that the HPO diagnosis has been performed in organisations over a time period of at least 2 years, demonstrating improvements over that period in both the HPO score and the organisation's performance (De Waal 2012; De Waal \& De Haas 2016).

\section{The case company}

Security Ltd (the company asked to remain anonymous) is a dominant player in the South African security industry with some 7000 employees. It provides $24 / 7$ alarm monitoring, armed response and static guarding services to half a million South African homes and businesses. The organisation was based on a regional operational structure with four regions in South Africa, each reporting to the South African head office. Each region had an executive managing director (MD) with all regions reporting to their own MD. Below each MD there were functional department heads, included Sales, Operations, Finance, Marketing, Information Systems and Technical Services.

Because of economic pressure the organisation introduced a rationalisation and restructuring program which enabled it to increase earnings before interest and tax (EBIT) growth in a downward market. The intention of the restructuring was to become more flexible and dynamic, enabling service managers to focus strictly on core deliverables and enhancing customer service. However, the restructuring compounded the already high anxiety levels of staff that resulted from the changing reporting lines, re-alignment from a regional functional structure to a matrix structure and standardisation of functions. Many positions were terminated and even more moved to centralised locations. In general, staff felt that the company's profitability was maintained at their expense which impacted the commitment of the staff members and could become a threat for the future growth and profitability of the company. Aware of these problems, the management of Security Ltd decided to conduct a diagnosis of its strengths and weaknesses in order to identify areas where management attention was needed to strengthen the organisation. For this purpose De Waal's HPO framework was selected, on the advice of the two South African authors.

\section{Research approach and results}

The context of the study, which has been outlined above, is important in understanding the dynamics that are present in order to be sensitive to the management behaviour that takes place (Yin 2009). Zikmund (2003) states that exploratory research has three purposes: diagnosing the current situation, evaluating alternative possibilities and generating new ideas. The case study, described in this article, therefore seeks to establish the current levels of high performance within Security Ltd, considering alternatives to current organisational proceedings and behaviours where appropriate, and generate recommendations to stimulate high performance within the organisation.
To obtain the necessary data, the HPO questionnaire was circulated to all office-based employees within the organisation (field workers and mobile staff were explicitly excluded because of access constraints). The population of this study therefore consisted of the 2222 office-based staff within the organisation that represents $28 \%$ of the total organisation. The HPO questionnaire was emailed to all office-based supervisory and management employees of the company. Because of the voluntary nature of the survey, a relatively low response rate of $9.8 \%$ was experienced (of the 261 responses, 26 responses were rejected because of incomplete results, resulting in 235 valid responses). More than a third of the responses were received from the head office, $20 \%$ originated from the Central and Northern regions, and the remaining $43 \%$ was received from the Western Cape and East Coast regions. Most respondents were based in the large regional offices, with $20 \%$ indicating that they operated from the smaller branch offices. The remaining $10 \%$ were not based at any specific office.

Using the data obtained, the reliability of the five factors was established by calculating the Cronbach's alpha coefficient (see Table 1). Generally, a Cronbach's alpha of equal or greater than 0.70 is acceptable as a reliable internal consistency indicator (Institute for Digital Research and Education 2013). The data revealed very good Cronbach's alpha scores - all in excess of 0.8 which provided strong empirical evidence for internal consistency.

Subsequently, the HPO scores for Security Ltd were calculated, averaged and represented in a graph indicating the company's scores relative to the normative scores of an HPO (see Figure 1).

TABLE 1: Cronbach's alpha scores for the five high-performance organisation factors.

\begin{tabular}{lc}
\hline Factor & Cronbach's alpha \\
\hline Management quality & 0.96 \\
Openness and action orientation & 0.86 \\
Long-term orientation & 0.82 \\
Continuous improvement & 0.94 \\
Employee quality & 0.84 \\
\hline
\end{tabular}

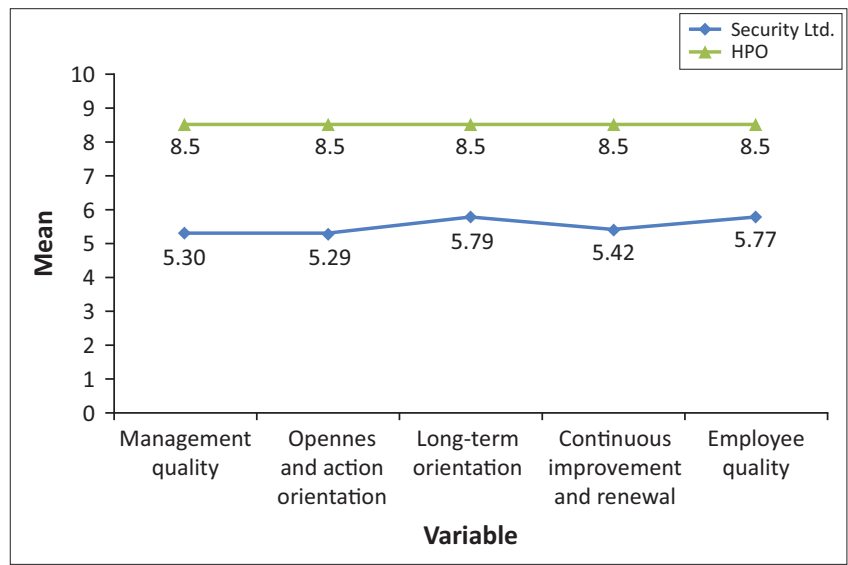

HPO, high-performance organisation.

FIGURE 1: Mean factor scores compared to the proposed normative means for a high-performance organisation. 
TABLE 2: Mean factor scores by length of service.

\begin{tabular}{lcc}
\hline Factors & \multicolumn{2}{c}{ Length of service } \\
\cline { 2 - 3 } & $<$ 1 year & $>$ 10 years \\
\hline Management quality & 5.56 & 5.00 \\
Openness and action orientation & 5.77 & 5.12 \\
Long-term orientation & 6.38 & 5.33 \\
Continuous improvement and renewal & 5.81 & 5.28 \\
Employee quality & 6.05 & 5.00 \\
\hline
\end{tabular}

From Table 2 it is apparent that Security Ltd fell short of the desired standard on all five factors and that this shortfall was most marked on Openness and Action Orientation. It is apparent that, on the basis of this assessment, the organisation could not be classified as an HPO. In addition, a more detailed analysis of the mean scores on each of the 35 individual HPO characteristics revealed that there were significant differences between characteristics, even within factors (see Appendix 1).

Because of the relatively small sample, the size of the various subgroups in this study was too small to allow for statistically significant results to be obtained. However, even with this limitation, the results of such an analysis suggest that, with a larger sample, significant conclusions could be drawn. One example will illustrate this. An analysis based on length of tenure at the company provides an interesting insight into the perceptions of staff. Those with less than 1 year of service returned higher mean scores across all five factors when compared with staff who had service of over 10 years (see Table 2).

Because of the small number of respondents in each cell, it was not possible to establish whether these observed differences were statistically significant, although the trend across all five factors does seem to indicate that length of service has a consistent effect on the assessment of these two categories of staff: the longer individuals have been with the organisation, the less favourable their assessment. This result has been found in previous studies using the HPO framework (De Waal, Peters \& Broekhuizen 2017). The difference in perception seems to be caused by the fact that people who have been at the company a shorter period of time, in general, have less access to comparative information than managers. These managers have worked longer at the company and, as a result, are more realistic about the organisation's functioning. They are well aware that improvements often take more time than expected (or desired) and therefore score more conservatively.

\section{Analysis \\ High-performance organisation factor: Management quality}

Leadership has a profound effect on developing a high performance culture. In order to lend credibility to the high performance aspiration in an organisation, it is critical that leadership set the example and the tone by uncompromising commitment. Even though the research results at Security Ltd indicate the overall strongest characteristic is the management focus on results, the Management quality factor still only rates at 5.30 which is a long way from the desired 8.50 (De Waal 2012). It seems that management input towards achieving the desired organisational results is lacking - something that is illustrated by the fact that the speed of management's decision-making and action-taking are rated as very low. This indecisiveness may, in turn, be the cause of the average trust in leadership amongst employees. The research results indicate a clear starting point for a management intervention aimed at setting the tone for high performance by aligning aspiration with execution. Such a step results in leaders, and thus employees who behave consistently with the organisational strategy and philosophy and therefore 'walk the talk' (American Management Association 2007; Lennick \& Kiel 2011). This is important, because, as Blanchard (2010) estimates, leaders' actions are at least three times as important as their words: people assess leaders on what they do and inconsistent or uncommitted action will result in the loss of commitment.

\section{High-performance organisation factor: Openness and action orientation}

Trust can be increased through open communication and sharing of information from management to employees; thus encouraging people to act like owners of the organisation. Providing people with more complete information communicates trust in them from the side of management and creates a sense of responsibility that mobilises people to appreciate how their contributions impact the greater organisation (O'Brien 2001). Kumar (2000) suggested that organisations pursue cooperative labour-management relations to foster a participatory enterprise culture. Such an approach serves to make organisations lean, cost-efficient and flexible in order to be more responsive to changing markets and technologies. Because it is proposed that an organisation's consistency of strategic approach helps to determine its success, Security Ltd exhibits a need to create a clear vision that is supported by a flexible and achievable strategic plan; thus setting the benchmarks for the desired individual and group behaviours.

In the same vein as the strong management focus on results, the 'performance-drivenness' of the organisation emerges as the highest ranked characteristic. The analysis suggests that management has not made enough provisions to stimulate an environment that supports the focus on results by creating openness, dialogue and knowledge sharing (Detert, Burris \& Harrison 2010; De Waal 2012). Rapid leadership intervention is therefore proposed to create an environment where openness and resulting action-taking can flourish.

\section{High-performance organisation factor: Long-term orientation}

The research results indicate that Security Ltd is not adequately growing internal talent, growing through partnerships with suppliers and/or customers, providing a 
secure workplace for employees or aiming to serve its customers as best as possible. This raises the question as to whether the organisation is focussing its attention and resources in the right areas, thus running the risk that talented employees may seek alternative opportunities. The authors observed signs of this in a number of senior, long-tenure employees recently leaving the company and several cost-cutting initiatives that were to the detriment of the operational integrity of the organisation. The uncertainty that exists in the company about its long-term vision seems to have created uncertainty and unease about where the attention of management and employees should be focussed. Leadership intervention is required to formulate clear goals for the company that go beyond the financial year-end, that address where investments should be made in time and resources in the organisation, and how these will benefit customers. These goals need to be understood by each member of the organisation to ensure all stakeholders are looked after in a structured way (Barwise \& Meehan 2011).

\section{High-performance organisation factor: Continuous improvement and renewal}

While in many organisations strategies, in general, become increasingly elaborate and difficult to execute, HPOs focus strictly on the distinguishing factors to facilitate easy and effective execution. High performance leaders therefore continuously try to find uniqueness in the content and execution of their strategy, and they ponder the question of what makes their organisation different so that customers choose them above competitors (Shenkar 2010; Taylor \& LaBarre 2006). They realise that, as Kaliprasad (2006) states, their organisation's long-term success depends on its ability to sustain the delivery of quality products and services. This, in turn, depends on the organisation's ability to simplify its internal processes. In practice, even when the organisation does continuously roll out new products and solutions, their impact often fails as a result of poor execution (McLean \& Antony 2014). Evidence of this problem can also be found at Security Ltd, as the centralisation restructuring seems to be still largely ineffective 18 months after implementation. This could be, in part, a result of the inefficient bureaucratic control systems which resulted in extensive customer frustration. The situation was further aggravated by weak and errorprone internal reporting systems which ultimately came at the expense of time available for serving customers. This issue could be addressed by improving the systems environment and introducing effective performance management systems to allow for efficient electronic reporting in order to not only improve accuracy, but free up time for staff members to serve customers (De Waal 2013).

\section{High-performance organisation factor: Employee quality}

A central theme throughout the HPO scores of Security Ltd is management's guidance, actions and the associated environment which appeared to fail in its support to drive result. This theme emerged again in management's inability to inspire members to achieve extraordinary results and to train them in flexibility and resilience. High-performance organisations rely on the quality of their people, and they therefore find it critical to hire people with incurable curiosity who want to be challenged, want to have responsibility, ask to be held accountable and want to perform better. It was obvious that management would need to step up their efforts to motivate their employees and also - in line with the action to be taken to improve the HPO factor Continuous Improvement and Renewal - to simplify the internal process environment to free up the time of employees so they can start developing themselves more, both individually and in collaboration with colleagues (Spreitzer \& Porath 2012; Välikangas 2010; Zenger, Folkman \& Edinger 2009).

\section{Conclusion, limitations and further research}

The most significant conclusion of this study is that De Waal's HPO framework can provide a theoretically and empirically robust instrument that allows researchers to investigate the perceptions of organisational members at a South African organisation regarding the five factors of high performance. While providing an overview of organisationwide perceptions, that can be compared to normative standards, the study results also allow for a more detailed and nuanced analysis across the range of 35 characteristics that are of interest to professional managers. This study has also given some evidence that further analysis at the level of subgroups has the potential to highlight differences between the perceptions of these subgroups. There is therefore no doubt that the use of an instrument, such as the one reported on in this study, enables managers to identify areas of weakness in their organisations and provides sufficient detailed information to enable them to engage with the issue of what remedial action is appropriate and desirable.

There are, however, several limitations to this study. The main limitation is that the authors did not interview organisational members; thus a more detailed and accurate picture of the weak areas of the organisation (as indicated by the HPO scores) could not be obtained and more accurate improvement actions could not be formulated. In future studies, researchers should therefore agree in advance with management that they will get access to organisational members in order to be able to develop a fuller picture of the status of the organisation. Another limitation is that the number of responses was not sufficient to be able to analyse with confidence the results and situations of various subgroups and locations in the case company. In future research, more effort should be spent on getting an adequate number of responses.

A further limitation is that the research was only performed at one South African organisation. So great care should be taken not to generalise to other South African organisations on the basis of these findings. Further research is called for at 
other South African organisations. Finally, the best test of the usefulness of De Waal's HPO framework is in following the organisation during its improvement journey. The opportunity exists for research to be conducted by way of a longitudinal study at the case company to evaluate whether its results improve based on the recommendations from the HPO diagnosis.

\section{Acknowledgements Competing interests}

\section{Authors' contributions}

C.H. developed the study, conducted the research at the case company and wrote the initial draft of this paper. A.W. rewrote the initial draft and was responsible for the final manuscript. P.P. supervised C.H.'s study and commented on the manuscript drafts.

\section{References}

Abor, J., 2007, 'Debt policy and performance of SMEs', The Journal of Risk Finance 8(4), 364-379. https://doi.org/10.1108/15265940710777315

American Management Association, 2007, How to build a high-performance organization: A global study of current trends and future possibilities 2007-2017, American Management Association, New York, viewed 15 February 2013, from www.amajapan.co.jp/e/pdf/HRI_HIGH-PERFORMANCE_Organization.pdf

Barwise, P. \& Meehan, S., 2011, Beyond the familiar, long-term growth through customer focus and innovation, Jossey-Bass, San Francisco, CA.

Blanchard, K., 2010, Leading at a higher level, revised and expanded edition: Blanchard on leadership and creating high performing organizations, FT Press, Upper Saddle River, NJ.

Bodnar, J., 2012, The private security industry, Southern African Catholic Bishops' Conference, Briefing paper 313, Parliamentary Liaison Office, Cape Town.

Bowen, P., Cattell, K., Edwards, P. \& Jay, I., 2010, 'Value management practice by South African quantity surveyors', Facilities 28(1/2), 46-63. https://doi.org/ $10.1108 / 02632771011011396$

Comins, N.R. \& Kraemer-Mbula, E., 2016, Innovation hubs in Africa, in O. Adesida, G. Karuri-Sebina \& J. Resend-Santos (eds.), Innovation Africa, emerging hubs of excellence, pp. 37-98, Emerald Group Publishing Limited, Bingley.

Dawes, J., 1999, 'The relationship between subjective and objective company performance measures in market orientation research: Further empirical evidence', Marketing Bulletin 10, 65-76.

Denton, M. \& Vloeberghs, D., 2003, 'Leadership challenges for organisations in the New South Africa', Leadership \& Organization Development Journal 24(2), 84-95. https://doi.org/10.1108/01437730310463279

Detert, J.R., Burris, E.R. \& Harrison, D.A., 2010, 'Debunking four myths about employee silence', Harvard Business Review 88(6), 26-30.

De Waal, A.A., 2010 [2006], The characteristics of a high performance organization, viewed 16 March 2015, from http://ssrn.com/abstract=931873

De Waal, A.A., 2012, What makes a high performance organization: Five validated factors of competitive performance that apply worldwide, Global Professional Publishing, Enfield.

De Waal, A.A., 2013, Strategic performance management. A managerial and behavioural approach, 2nd edn., Palgrave MacMillan, Basingstoke.

De Waal, A.A. \& De Haas, J., 2016, 'Longitudinal research into the effects of the high performance organisation framework: The case of NEH the Philippines', pape presented during the PMA 2016 Conference, 26-29 June 2016, Edinburgh.

De Waal, A.A., Peters, L. \& Broekhuizen, M., 2017, 'Do different generations look differently at high performance organizations?', Journal of Strategy and Management 10(1), 86-101.

Gokay, B., 2009, The 2008 world economic crises. Global shifts and faultlines, Global Research, Centre for Research on Globalisation, Montreal.

Goldstein, A. \& Prichard, W., 2009, South African multinationals: Building on a unique legacy, in R. Ramamurti \& J.V. Singh (eds.), Emerging multinational in emerging markets, pp. 244-279, Cambridge University Press, Cambridge.

Hair, J.F., Anderson, R.E., Tatham, R.L. \& Black, W.C., 1998, Multivariate data analysis, Prentice Hall, Upper Saddle River, NJ.

Heap, J. \& Bolton, M., 2004, 'Using perceptions of performance to drive business improvement', in A. Neely, M. Kennerly \& A. Waters (eds.), Performance measurement and management: Public and private, pp. 1085-1090, Centre for Business Performance, Cranfield University.

Hill, C.W.L., 2011, International business, Competing in the global marketplace, 8th edn., McGraw-Hill, New York.

Hough, J., Thompson Jr, A.A., Strickland III, A.J. \& Gamble, J.E., 2011, Crafting and executing strategy, creating sustainable high performance in South Africa: Text, readings and cases, 2 nd edn., McGraw-Hill, Maidenhead.

Institute for Digital Research and Education, 2013, SSPS FAQ: What does Cronbach's Alpha mean?, viewed 26 October 2014, from http://www.ats.ucla.edu/stat/spss/ faq/alpha.html

Jing, F.F. \& Avery, G.C., 2008, 'Missing links in understanding the relationship between leadership and organizational performance', International Business \& Economics Research Journal 7(5), 67-78.

Kaliprasad, M., 2006, 'The human factor II: Creating a high performance culture in an organization,' IEEE Engineering Management Review 39(1), 25-35. https://doi. org/10.1109/EMR.2011.5729970

Khoza, R.J. \& Adam, M., 2005, The power of governance, enhancing the performance of state-owned enterprises, Pan Macmillan, Hyde Park.

Kokt, D., 2003, 'The impact of cultural diversity on work team performance: A SouthAfrican perspective', Team Performance Management: An International Journal $9(3 / 4), 78-83$.

Kumar, P., 2000, Rethinking high performance work systems, Industrial Relations Centre Press, Kingston.

Lennick, D. \& Kiel, F., 2011, Moral Intelligence 2.0, enhancing business performance and leadership success in turbulent times, Prentice Hall, Upper Saddle River, NJ.

Luthans, F., Van Wyk, R. \& Walumbwa, F.O., 2004, 'Recognition and development of hope for South African organizational leaders', Leadership \& Organization Development Journal 25(6), 512-527. https://doi.org/10.1108/01437730410556752

Mahajan, V., 2009, Africa Rising, how 900 million African consumers offer more than you think, Wharton School Publishing, Upper Saddle River, NJ.

Matear, S., Gray, B.J. \& Garrett, T., 2004, 'Market orientation, brand investment, new service development, market position and performance for service organizations', International Journal of Service Industry Management 15(3), 284-301. https:// doi.org/10.1108/09564230410540944

Mayer, C.H. \& Louw, L., 2011, 'Managerial challenges in South Africa', European Business Review 23(6), 572-591. https://doi.org/10.1108/09555341111175417

McCourt, W., 2006, The human factor in governance, managing public employees in Africa and Asia, Palgrave MacMillan, Basingstoke.

McFarlin, D.B., Coster, E.A. \& Mogale-Pretorius, C., 1999, 'South African management development in the twenty-first century', Journal of Management Development 18(1), 63-78. https://doi.org/10.1108/02621719910250474

McLean, R. \& Antony, J., 2014, 'Why continuous improvement initiatives fail in manufacturing environments? A systematic review of the evidence,' International Journal of Productivity and Performance Management 63(3), 370-376. https:// doi.org/10.1108/IJPPM-07-2013-0124
doul

Nienaber, H., 2007, 'Assessing the management status of South Africa', European Business Review 19(1), 72-88. https://doi.org/10.1108/09555340710714153

O'Brien, R.C., 2001, Trust. Releasing the energy to succeed, John Wiley \& Sons, Chichester.

Oyewobi, L.O., Windapo, A.O. \& Cattell, K.S., 2013, 'Impact of business diversification on South African construction companies' corporate performance', Journal of Financial Management of Property and Construction 18(2), 110-127. https://doi. org/10.1108/JFMPC-12-2012-0045

Sharma, R., 2012, Breakout nations, in pursuit of the next economic miracles, Allen Lane, Penguin Books, London.

Shenkar, O., 2010, Copycats, how smart companies use imitation to gain a strategic edge, Harvard Business Press, Boston, MA.

Slabbert, A. \& Ukpere, W.I., 2011, 'A comparative analysis of the Chinese and South African work Ethic', International Journal of Social Economics 38(8), 734-741. https://doi.org/10.1108/03068291111143929

Spreitzer, G. \& Porath, C., 2012, 'Creating sustainable performance', Harvard Business Review 90(1/2), 92-99.

Strauss, A.C. \& du Toit, A.S.A., 2010. 'Competitive intelligence skills needed to enhance South Africa's competitiveness', Aslib Proceedings 62(3), 302-320. https://doi org/10.1108/00012531011046925

Taylor, W.C. \& LaBarre, P., 2006, Mavericks at work, why the most original minds in business win, Harper, London.

Välikangas, L., 2010, The resilient organization, how adaptive cultures thrive even when strategy fails, McGraw-Hill, New York.

Viljoen, C., 2016, IMF: Egypt overtakes SA as Africa's second largest economy Moneyweb, viewed 06 June 2016, from https://www.moneyweb.co.za/news/ economy/imf-egypt-overtakes-sa-africas-second-largest-economy/

Yin, R., 2009, Case study research: Design and methods, 2nd edn., Sage, Thousand Oaks, CA.

Zenger, J.H., Folkman, J.R. \& Edinger, S.K., 2009, The inspiring leader, unlocking the secrets of how extraordinary leaders motivate, McGraw-Hill, New York.

Zikmund, W.G., 2003, Business research methods, 7th edn., Thomson South-Western, Mason, IA. 


\section{Appendix 1}

This appendix lists the five high-performance organisation factors, with accompanying characteristics and gives the scores of Security Ltd.

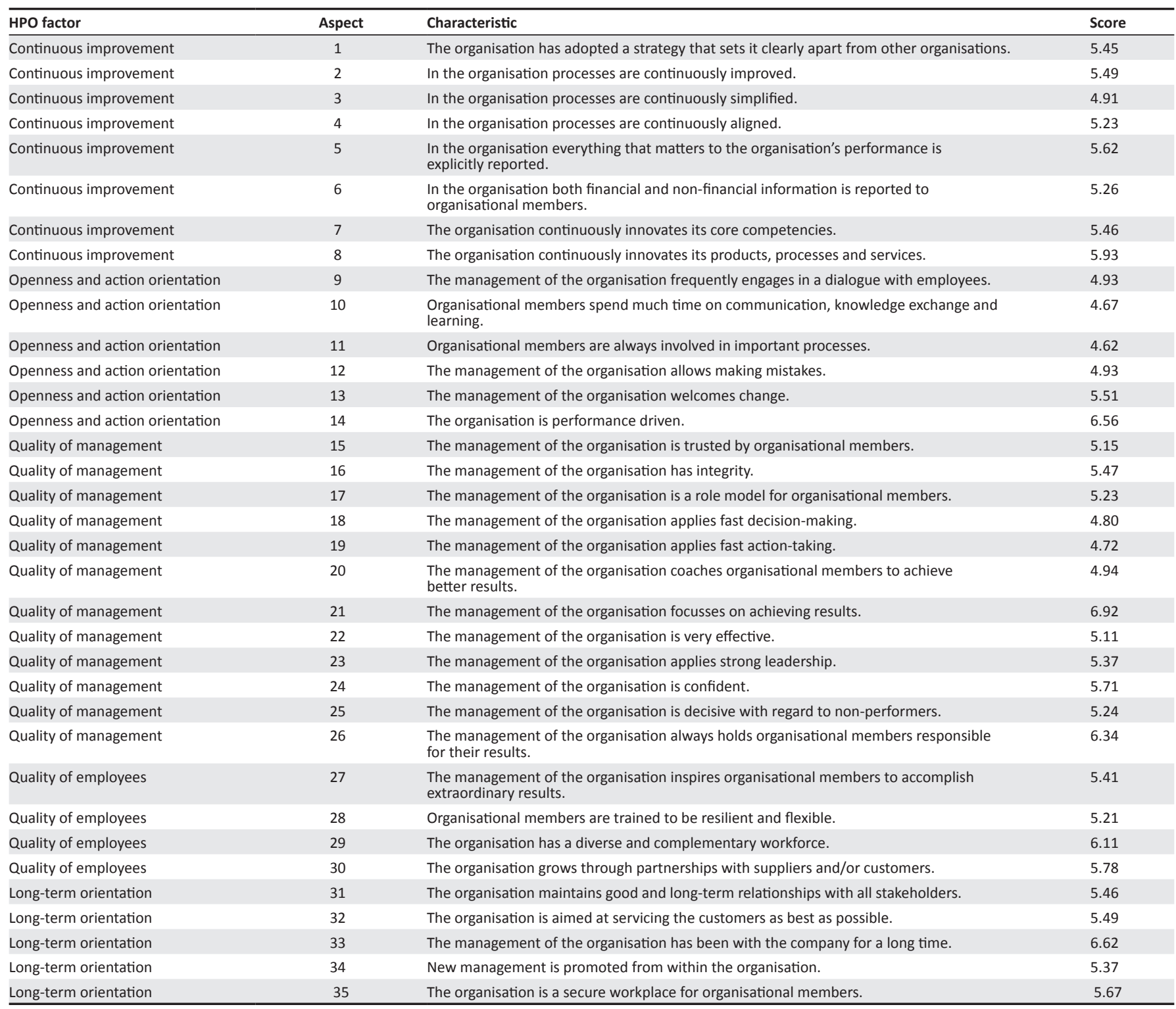

